\title{
Pemetaan Sebaran Total Suspended Solid (TSS) Menggunakan Citra Landsat Multitemporal dan Data In Situ (Studi Kasus : Perairan Muara Sungai Porong, Sidoarjo)
}

\author{
Luki Indeswari, Teguh Hariyanto, dan Cherie Bhekti Pribadi \\ Departemen Teknik Geomatika, Fakultas Teknik Sipil Lingkungan dan Kebumian, \\ Institut Teknologi Sepuluh Nopember (ITS) \\ e-mail: cheriepribadi@gmail.com
}

\begin{abstract}
Abstrak-Sungai Porong merupakan kawasan pembuangan lumpur Lapindo yang telah terjadi sejak tahun 2006 hingga sekarang. Aliran sungai yang deras menyebabkan terbawanya lumpur Lapindo menuju muara sungai Porong dan pengaliran lumpur telah menimbulkan sedimentasi di muara sungai Porong dan pesisir TimurSidoarjo. Maka dari itu, pengamatan terhadap sebaran TSS (Total Suspended Solid) dibutuhkan untuk mengetahui kualitas air di suatu perairan. Dalam penelitian ini, pengamatan terhadap sebaran TSS dilakukan dengan menggunakan metode penginderaan jauh dengan memanfaatkan Citra Satelit Landsat 7 tahun 2000, dan Landsat 8 tahun 2013, 2014, 2015, 2016, dan 2017, serta data in situ berupa sampel air sejumlah 20 titik. Data citra satelit Landsat8 L1T tahun 2017 diolah menggunakan 5 algoritma TSS yaitu Algoritma Syarif Budiman(2004), Algoritma Parwati(2006), Algoritma Guzman \& Santaella(2009), Algoritma Nurahida Laili (2015), dan Algoritma Jaelani (2016). Dari hasil pengolahan data Citra Satelit Landsat-8 L1T tahun 2017 didapatkan hasil algoritma yang memiliki nilai absolut error terkecil adalah Algoritma Budhiman (2004), dengan hasil Normalized Mean Error (NMAE) sebesar 19,53\%, nilai tersebut membuktikan bahwa nilai TSS Algoritma Budhiman (2004) adalah algoritma yang paling sesuai untuk menjelaskan keadaan konsesntrasi TSS di perairan Muara Sungai Porong, sehingga algoritma tersebut dipilih untuk kemudian dite rapkan pada citra Landsat-7 L1T tahun 2000, dan Landsat-8 L1T tahun 2013, 2014, 2015, 2016. Dari penerapan citra Landsat multitemporal didapatkan hasil konsentrasi TSS di Perairan Muara Sungai Porong yang terendah pada tahun 2015 yaitu $10,22 \mathrm{mg} / \mathrm{L}$ hingga $60,08 \mathrm{mg} / \mathrm{L}$, dan tertinggi pada tahun 2013 dengan nilai TSS berkisar antara $11,52 \mathrm{mg} / \mathrm{L}$ hingga 92,16 $\mathrm{mg} / \mathrm{L}$, dan tahun 2014 yaitu berkisar antara $10,28 \mathrm{mg} / \mathrm{L}$ hingga 81,17 mg/L. Menurut Keputusan Menteri Lingkungan Hidup No. 51 tahun 2004 tentang Baku Mutu Air Laut untuk Biota Laut, standar kualitas air laut untuk parameter TSS adalah 80 mg / L yang berarti pada tahun 2013, dan pada tahun 2014 perairan di muara Sungai Porong dapat dikatakan tidak baik karena melebihi standar kualitas baku yang telah ditentukan.
\end{abstract}

Kata Kunci-TSS, Algoritma TSS, Perairan Muara Sungai Porong, Keputusan Menteri Negara Lingkungan Hidup Nomor 51 Tahun 2017.

\section{PENDAHULUAN}

$\mathrm{P}$ ERATURAN Pemerintah No. 82 Tahun 2001 tentang Pengelolaan Kualitas Air dan Pengendalian Pencemaran Air mendefinisikan pencemaran air sebagai masuknya atau dimasukkannya makhluk hidup, zat, energi, dan atau komponen lain ke dalam air oleh kegiatan manusia, sehingga kualitas air turun sampai ke tingkat tertentu yang menyebabkan air tidak dapat berfungsi sesuai dengan peruntukannya $^{[5]}$. Kondisi tersebut dapat menyebabkan terganggunya kelangsungan hidup biota-biota yang ada di sekitarnya, seperti pada perikanan, ekosistem pesisir, dan laut (mangrove, padanglamun, terumbu karang), yang berdampak lebih luas terhadap penurunan pendapatan masyarakat pesis ir yang menggantungkan hidupnya pada produktivitas hayati di wilayah pesisir dan pantai [1].

Sungai Porong merupakan kawasan pembuangan lumpur Lapindo yang telah terjadi sejak tahun 2006 hingga sekarang. Aliran sungai yang deras menyebabkan terbawanya lumpur Lapindo menuju muara sungai Porong dan pengaliran lumpur telah menimbulkan sedimentasi di muara Porong dan pesisir Timur Sidoarjo. Maka dari itu diperlukan adanya perhitungan nilai TSS untuk mengevaluasi apakah air laut muara sungai Porong masih tergolong perairan yang baik atau sudah tercemar.

Dalam penelitian ini, permasalahan yang dibahas adalah bagaimana nilai konsentrasi Total Suspended Solid (TSS) atau padatan tersuspensi total di Perairan Muara Sungai Porong, Kabupaten Sidoarjo pada tahun 2000, 2013, 2014, 2015, 2016, dan 2017 dengan menggunakan citra satelit Landsat 7 dan 8, serta data in situ. Citra Landsat 7 tahun 2000 digunakan untuk mengetahui keadaaan konsentrasi TSS pada perairan muara sungai Porong sebelum bencana lumpur Lapindo terjadi, karena pada landsat 7 terjadi kerusakan pengambilan gambar di tahun 2003, oleh karena itu data yang digunakan adalah landsat 7 tahun 2000 yang memiliki kualitas gambar citra paling baik. Lands at 8 diluncurkan pada tahun 2013, maka dari itu data y ang digunakan adalah landsat 8 untuk mengetahui konsentrasi TSS setelah terjadinya bencana lumpur Lapindo hingga saat ini, selain itu untuk mengevaluasi konsentrasi TSS Perairan Muara Sungai Porong pada tahun-tahun tersebut terhadap Keputusan Menteri Lingkungan Hidup No. 51 Tahun 2004 tentang Baku Mutu Air Laut.

\section{METODE PENELITIAN}

A. Lokasi

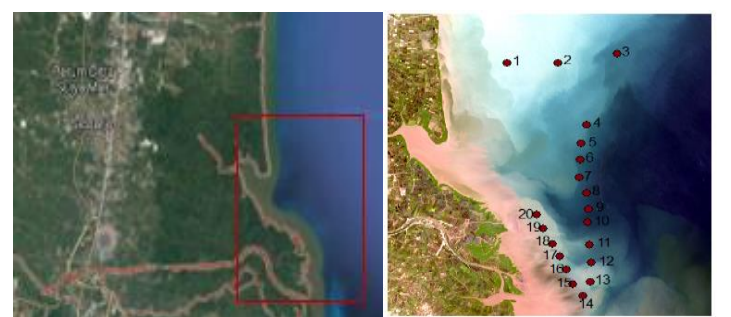

Gambar 2.1 Lokasi Penelitian Studi, dan Sebaran Titik Sampel Data Lap angan

(Sumber : Google Earth, 2017, Citra Landsat 8, 2017) 
Lokasi penelitian dari studi ini adalah muara sungai Porong, Kabupaten Sidoarjo, Jawa Timur. Kawasan ini secara geografis terletak di antara $7^{\circ} 21^{\prime} 3.22^{\prime \prime}-7^{\circ} 44^{\prime} 57.48^{\prime \prime}$ LS dan $112^{\circ} 47^{\prime} 53.59^{\prime \prime} 113^{\circ} 22^{\prime} 36.48^{\prime \prime}$ BT dengan batas selatan Kabupaten Pasuruan, batas barat Kabupaten Mojokerto, batas utara Selat Madura, dan batas timur Laut Bali.

\section{B. Bahan dan Peralatan}

\section{Bahan}

a. Citra Satelit Landsat-7 L1T tahun 2000 path/row $118 / 65$

b. Citra Satelit Landsat-8 L1T tahun 2013, 2014, 2015, 2016, dan 2017 path/row 118/65

c. Data Sampel Air Perairan Muara Sungai Porong sejumlah 20 sampel.

2. Perangkat Keras
a. GPS Handheld
b. Peralatan Pengambilan Sampel Air
c. Peralatan Uji Laboraturium Sampel Air

3. Perangkat Lunak
a. Windows 10
b. Microsoft Office 2016
c. ArcMap 10.3
d. ENVI 5.1 dan ENVI Classic
e. SNAP Desktop

\section{Tahap Pengolahan Data}

Adapun tahapan pengolahan data yang dilakukan dalam penelitian ini, yaitu :

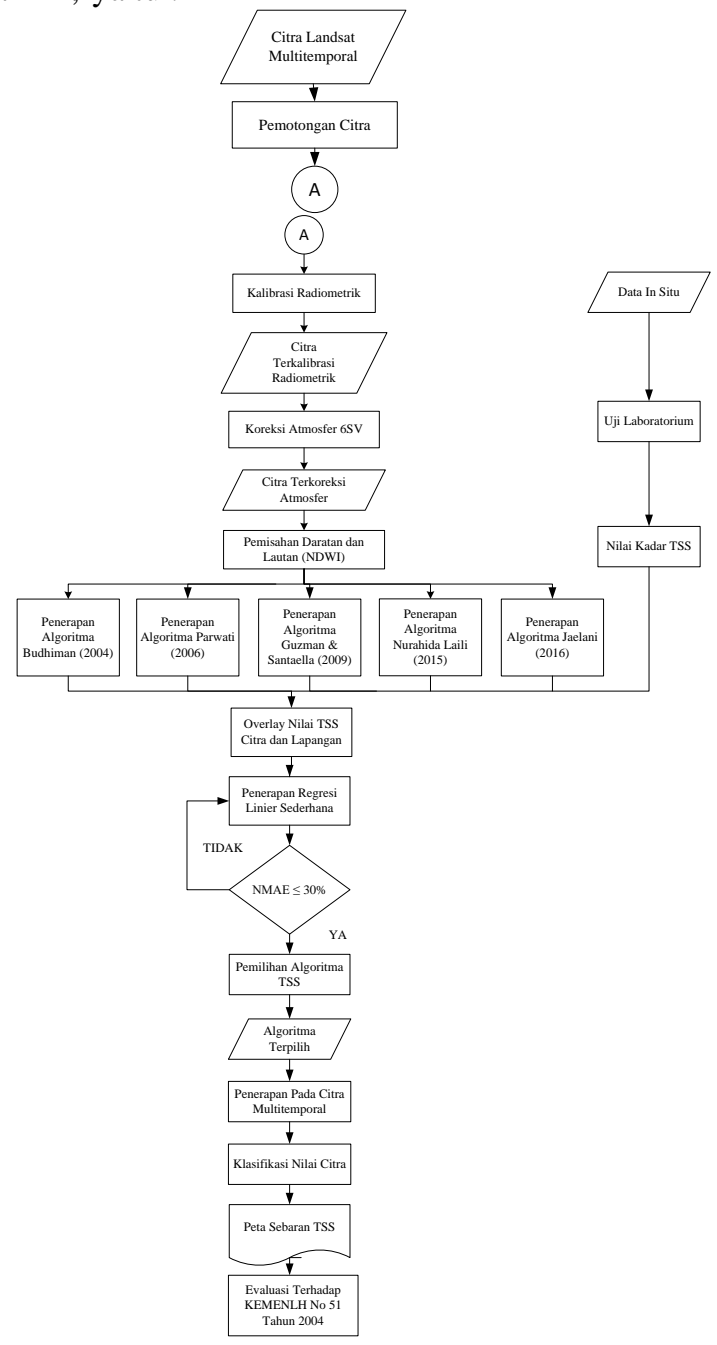

Gambar 1. Diagram Alir Pengolahan Data a. Pemotongan Citra (Cropping)

Sebelum citra landsat diolah dilakukan pemotongan citra sesuai dengan lokasi penelitian yang ditentukan agar memudahkan proses pengolahan data selanjutnya., selain itu agar tidak memakan banyak memori untuk menyimpan hasil pengolahan data citra.

b. Koreksi Radiometrik

Koreksi radiometrik terdiri dari dua tahap; kalibrasi radiometrik, dan koreksi atmosferik.

i. Kalibrasi radiometrik dilakukan dengan mengubah nilai DN (Digital Number) menjadi nilai TOA (Top of Atmosphere) Radiance atau Reflectance untuk menghilangkan distorsi radiometrik yang disebabkan oleh posisimatahari.

$$
\rho \lambda=\mathrm{M} \rho * \mathrm{Qcal}+\mathrm{A} \rho
$$

Keterangan :

$\rho \lambda=$ nilai reflektan padaband ke i $(W m-2 s r-1 \mu m-1)$

$\mathrm{M} \rho=$ Faktor skala pengali radian untuk setiap band (RADIANCE_MULT_BAND_n) dari metadata, $\mathrm{n}$ adalah nomor band).

A $\rho=$ Faktor skala penjumlah Radian untuk band (RADIANCE_ADD_BAND_n dari metadata, dimana $\mathrm{n}$ adalah nomor band)

Qcal $=$ Quantized and calibrated standard product pixel values $(\mathrm{DN})$

ii. Koreksi atmosfer adalah koreksi untuk menghilangkan kesalahan radiansi yang terekam pada citra sebagai akibat dari hamburan atmosfer (path radiance). Metode koreksi atmosfer salah satunya adalah metode Second Simulation of a Satellite Signal in the Solar Spectrum-Vector $(6 \mathrm{SV})$. Konversi nilai reflektan $(\rho T O A)$ ke koreksi atmosfer $(\rho B O A)$ menggunakan rumus berikut ini: $\mathrm{y}=\mathrm{Xa} *(\mathrm{~L} \lambda)-\mathrm{xb}$
$\mathrm{acr}=\mathrm{y} /(1+\mathrm{xc} * \mathrm{y})$

Keterangan :

acr $=$ reflektan terkoreksi atmosfer (Atmospheric Corrected Reflectance)

$(\lambda):=$ citra berformat radian

$X a, x b, x c=$ parameter koreksi $\mathrm{y}$ ang diperoleh dengan menjalankan perangkat lunak 6SV berbasis web yang ada di http://6s.Itdri.org/.

c. Setelah itu dilakukan pemisahan daratan dan lautan dengan menggunakan algoritma NDWI (Normalized Different Water Index).

$$
\mathrm{NDWI}=\frac{\text { Green }-N I R}{\text { Green }+N I R}
$$

d. Setelah citra landsat terkoreksi, maka citra tersebut ban dapat diolah menggunakan 5 Algoritma TSS yang telah ditentukan.

Algoritma TSS yang digunakan, antara lain :

Algoritma Syarif Budiman (2004)[2]

Algoritma Syarif Budiman memiliki studikasus di wilayah perairan Delta Mahakam, Kalimantan Timur, Indonesia.

$\operatorname{TSS}(\mathbf{m g} / \mathbf{l})=8,1429 *\left(\exp ^{(23,704 * 0,94 *(\operatorname{Rrs654,59)})}\right)$

- $\quad$ Algoritma Parwati (2006)[3]

Algoritma Parwati memiliki studikasus diwilayah perairan Berau, Kalimantan Timur, Indonesia. TSS $(\mathrm{mg} / \mathrm{l})=3,3238 * \exp ^{(34,099 *(654,59))}$ Algoritma Guzman - Santaella (2009)[4]

Algoritma Guzman \& Santaella memiliki studi kasus di wilayah perairan Mayagüez Bay, Puerto Rico.

TSS $(\mathrm{mg} / \mathrm{l})=602,63 *\left(0,0007 \mathrm{e}^{47,755^{*}(\operatorname{Rrs}(654,5))}\right)+$ 3,1481

(6) 
Algoritma Nurahida Laili (2015)[5]

Algoritma Nurahida Laili memiliki studi kasus di wilayah perairan Pulau Poteran, Sumenep, Madura, Jawa Timur, Indonesia.

TSS $(\mathrm{mg} / \mathrm{l})=31,42 *((\log (\operatorname{Rrs}(482,04)) /(\log$ $(\operatorname{Rrs}(654,59)))-12,719$

Algoritma Jaelani (2016)[6]

Algoritma Jaelani memiliki studikasus di wilayah perairan Gili Iyang, Sumenep, Madura, Jawa Timur, Indonesia.

$\log (\operatorname{TSS})=1.5212 *(\log (\operatorname{Rrs}(482,04)) / \log 10(\operatorname{Rrs}(561,41)))$ $-0.3698$

e. Pengolahan data in situ berupa sampel air laut diolah dengan uji laboraturium menggunakan metode gravimetri untuk mengetahui kondisi nilai TSS di muara sungaiPorong Sidoarjo pada saat itu.

f. Setelah didapatkan nilai TSS dari citra Landsat 8 dan data in situ, kedua nilai tersebut diiverlaykan, kemudian dilakukan uji statistik data citra dengan data TSS lapangan menggunakan regresi linier sederhana, untuk mengetahui kekuatan hubungan hasilnilai TSS citra dan TSS lapangan. Berikut adalah rumus uji korelasi yang digunakan :

$$
\mathrm{r}=\frac{\mathrm{n}\left(\sum \mathrm{xy}\right)-\left(\sum \mathrm{x}\right)\left(\sum \mathrm{y}\right)}{\sqrt{\left[\mathrm{n}\left(\sum \mathrm{x} 2\right)-\left(\sum \mathrm{x}\right)^{2}\left[\mathrm{n}\left(\sum \mathrm{y} 2\right)-\left(\sum \mathrm{y}\right)^{2}\right]\right.}}
$$

Keterangan :

$\mathrm{r}$ : Korelasi antar variabel

$\mathrm{x}$ : variabel bebas

y : variabel tak bebas

$\mathrm{n}$ : jumlah pengamatan

apabila nilai $r=+1$ atau mendekati positif $(+)$ satu berarti variabel $x$ mempunyai pengaruh yang kuat dan positif terhadap variabel $y$. Dan apabila $r=0$ atay mendekati nol (0) maka variabel $x$ kurang berpengarulh terhadap perkembangan variabel $y$

g. Uji validasi bertujuan untuk mengetahui ketepatan hasil nilai TSS algoritma pengolahan citra terhadap data $\frac{14}{15}$ situ. Uji validasi pada penelitian ini menggunakaing Normalized Mean Absolute Error (NMAE). Syarat minimum NMAE yaitu sebesar $\leq 30 \%$.

NMAE $(\%)=\frac{1}{N} \sum\left|\frac{x \text { estimated }, i-x \text { measured }}{x \text { measured }}\right| .100$

\begin{tabular}{|c|c|c|c|c|c|c|c|c|}
\hline No & Koordinat ( & meter) & TSS & TSS & TSS & TSS & TSS & TSS \\
\hline $\begin{array}{l}\text { satu } \\
\text { dan }\end{array}$ & $\begin{array}{l}\text { Easting } \\
\text { (X) }\end{array}$ & Northing (Y) & $\begin{array}{l}\text { In } \\
\text { Situ } \\
\text { (mg/ } \\
\text { L) }\end{array}$ & $\begin{array}{l}\text { Laili } \\
(\mathrm{mg} / \mathrm{L} \\
)\end{array}$ & $\begin{array}{l}\text { Budhi } \\
\text { man } \\
(\mathrm{mg} / \mathrm{L} \\
)\end{array}$ & $\begin{array}{l}\text { Parwa } \\
\text { ti } \\
(\mathrm{mg} / \mathrm{L} \\
)\end{array}$ & $\begin{array}{l}\text { Guzm } \\
\text { an } \\
(\mathrm{mg} / \mathrm{L} \\
\text { ) }\end{array}$ & $\begin{array}{l}\text { Jaelan } \\
\mathrm{i} \\
(\mathrm{mg} / \mathrm{L} \\
)\end{array}$ \\
\hline 90 & $711.185,09$ & $9.166 .884,06$ & 16 & 13,42 & 11,5 & 5,63 & 142 & 13,49 \\
\hline ullit & $711.331,87$ & $9.165 .336,33$ & 14 & 14,69 & 14,21 & 7,79 & 228,5 & 16,17 \\
\hline 12 & $711.432,34$ & $9.164 .127,86$ & 14 & 14,75 & 14,5 & 8,03 & 224,9 & 15,13 \\
\hline asin & $711.331,00$ & $9.162 .821,63$ & 18 & 17,88 & 26,88 & 20,67 & 487,2 & 17,81 \\
\hline 14 & $710.905,58$ & $9.161 .847,50$ & 20 & 18,02 & 24,48 & 17,91 & 447,3 & 17,5 \\
\hline & $710.387,42$ & $9.162 .687,04$ & 72 & 17,8 & 24,97 & 18,47 & 458,4 & 17,08 \\
\hline aाय & $709.981,49$ & $9.163 .673,28$ & 26 & 16,66 & 20,52 & 13,68 & 378,2 & 17,35 \\
\hline$\dot{x}$ & $709.591,01$ & $9.164 .544,98$ & 22 & 17,58 & 24,8 & 18,28 & 453,9 & 17,72 \\
\hline 18 & $709.183,68$ & $9.165 .430,99$ & 24 & 18,14 & 27,24 & 21,1 & 496,3 & 18,35 \\
\hline 19 & $708.649,86$ & $9.166 .448,72$ & 36 & 18,43 & 29,32 & 23,61 & 521,9 & 18 \\
\hline 20 & $708.300,93$ & $9.167 .404,06$ & 34 & 18,56 & 29,38 & 23,69 & 522,4 & 18,37 \\
\hline
\end{tabular}

Keterangan :

NMAE = Normalized Mean Absolute Error

$\mathrm{N} \quad=$ Jumlah data

$\mathrm{X}$ estimated $=$ Nilai hasil pengolahan

$\mathrm{X}$ measured $=$ Nilai hasil pengukuran lapangan y ang dianggap benar

h. Pemilihan algoritma yang paling sesuai dilakukan setelah mendapatkan hasil uji validasi. Algoritma TSS dengan nilai NMAE yang paling rendah akan dipilih, dan diterapkan pada citra Landsat-7 L1T tahun 2000, dan Landsat-8 L1T tahun 2013, 2014, 2015, 2016.

i. Setelah didapatkan hasil pengolahan data citra satelit dan data in situ, serta uji validasi telah selesai. Dilakukan klasifikasi nilai TSS untuk memudahkan proses pembuatan peta sebaran TSS. Nilai TSS diklasifikasikan menjadi 5 yaitu: 0 - $15 \mathrm{mg} / \mathrm{L}, 15,01-$ $25 \mathrm{mg} / \mathrm{L}, 25,01 \mathrm{mg} / \mathrm{L}-35 \mathrm{mg} / \mathrm{L}, 35,01-80 \mathrm{mg} / \mathrm{L}$, dan $>80 \mathrm{mg} / \mathrm{L}$.

j. Kemudian dilakukan analisa, dan evaluasi hasil kondisi TSS Perairan Muara Sungai Porong Sidoarjo pada tahun 2000, 2013，2014，2015，2016, dan 2017 terhadap Keputusan Menteri Negara Lingkungan Hidup No. 51 Tahun 2004 tentang Baku Mutu Air Laut untuk Biota Laut.

\section{HASIL DAN PEMBAHASAN}

\section{A. Perbandingan Nilai TSS Citra Satelit Landsat 8 dengan Nilai TSS Lapangan}

Dari hasil pengolahan citra satelit landsat 8 yang direkam pada tanggal 24 Agustus 2017 dengan menggunakan 5 algoritma yang telah ditentukan, yaitu : Algoritma Syarif Budiman (2004), Algoritma Parwati (2006), Algoritma Guzman \& Santaella (2009), Algoritma Nurahida Laili (2015), dan Algoritma Jaelani (2016), maka didapatkan nilai TSS seperti berikut :

Tabel 3.1

Tabel Hasil Nilai T SS Data In Situ dan TSSPengolahan Citra Satelit

\begin{tabular}{|c|c|c|c|c|c|c|c|c|}
\hline \multirow[t]{2}{*}{ No } & \multicolumn{2}{|c|}{ Koordinat (meter) } & \multirow[b]{2}{*}{$\begin{array}{l}\text { TSS } \\
\text { In } \\
\text { Situ } \\
(\mathrm{mg} / \mathrm{L} \\
)\end{array}$} & \multirow{2}{*}{$\begin{array}{l}\text { TSS } \\
\text { Laili } \\
\text { (mg/L } \\
\text { ) }\end{array}$} & \multirow[b]{2}{*}{$\begin{array}{l}\text { TSS } \\
\text { Budhi } \\
\text { man } \\
(\mathrm{mg} / \mathrm{L} \\
\text { ) }\end{array}$} & \multirow[b]{2}{*}{$\begin{array}{l}\text { TSS } \\
\text { Parwa } \\
\text { ti } \\
(\mathrm{mg} / \mathrm{L} \\
)\end{array}$} & \multirow[b]{2}{*}{$\begin{array}{l}\text { TSS } \\
\text { Guzm } \\
\text { an } \\
(\mathrm{mg} / \mathrm{L} \\
\text { ) }\end{array}$} & \multirow[b]{2}{*}{$\begin{array}{l}\text { TSS } \\
\text { Jaelan } \\
\mathrm{i} \\
(\mathrm{mg} / \mathrm{L} \\
)\end{array}$} \\
\hline & $\begin{array}{l}\text { Easting } \\
(\mathrm{X})\end{array}$ & Northing (Y) & & & & & & \\
\hline 1 & $706.602,05$ & $9.177 .816,94$ & 20 & 17,97 & 38,14 & 35,31 & 632,4 & 18,28 \\
\hline 2 & $709.515,77$ & $9.177 .821,32$ & 22 & 17,38 & 32,77 & 28 & 554 & 17,98 \\
\hline 3 & $712.892,65$ & $9.178 .446,08$ & 18 & 13,66 & 13,66 & 7,35 & 215 & 14,97 \\
\hline 4 & $711.170,62$ & $9.173 .555,51$ & 32 & 14,1 & 14,79 & 8,28 & 244 & 15,75 \\
\hline 5 & $710.832,36$ & $9.172 .250,56$ & 20 & 14,04 & 14,4 & 7,95 & 242,7 & 9,39 \\
\hline 6 & $710.802,99$ & $9.171 .180,48$ & 18 & 13,98 & 12,68 & 6,55 & 184,3 & 14,85 \\
\hline 7 & $710.732,97$ & $9.169 .930,92$ & 16 & 13,27 & 12,18 & 6,16 & 169,0 & 14,64 \\
\hline 8 & $711.119,92$ & $9.168 .891,86$ & 16 & 13,37 & 11,86 & 5,91 & 155,5 & 13,81 \\
\hline 9 & $711.264,78$ & $9.167 .770,95$ & 16 & 13,26 & 11,57 & 5,69 & 148,3 & 13,54 \\
\hline
\end{tabular}

B. Penerapan Regresi Linier dan Uji Validasi Hasil Pengolahan Data Citra dengan Hasil Data Lapangan

Penerapan regresi dilakukan pada nilai TSS hasil pengolahan citra Landsat-8 L1T pada tanggal 24 Agustus 2017 dengan menggunakan 4 algoritma TSS dan nilai TSS data in situ. Uji statistika ini dilakukan dengan menggunakan regresi linier sederhana yang bertujuan untuk mengetahui hubungan antara hasil pengolahan data citra dan data lapangan. Selain itu, dilakukan uji validasi dengan menggunakan NMAE untuk mengetahui apakah metode yang digunakan sesuai atau tidak, dengan toleransi $N M A E$ sebesar $\leq 30 \%$

Tabel 3.2

Hasil Penerapan Regresi dan Uji Validasi

\begin{tabular}{llll}
\hline \hline Algoritma & Regresi Linier & $\begin{array}{l}\text { Koefisien } \\
\text { Korelasi }\end{array}$ & NMAE \\
\hline $\begin{array}{l}\text { Budhiman } \\
(2004)\end{array}$ & 0,1218 & 0,349 & $19,53 \%$ \\
\hline Parwati(2006) & 0,101 & 0,317 & $39,85 \%$ \\
\hline \hline
\end{tabular}




\begin{tabular}{llll}
\hline \hline $\begin{array}{l}\text { Guzman \& } \\
\text { Santaella } \\
(2009)\end{array}$ & 0,16 & 0,40 & $8802 \%$ \\
\hline $\begin{array}{l}\text { Nurahida Laili } \\
(2015)\end{array}$ & 0,2064 & 0,454 & $26,77 \%$ \\
\hline Jaelani (2016) & 0,1003 & 0,316 & $25,75 \%$ \\
\hline \hline
\end{tabular}

Berdasarkan tabel di atas algoritma TSS yang memiliki koefisien korelasi lebih tinggi dibanding algoritma TSS yang lain, belum tentu algoritma tersebut lebih sesuaidengan hasil nilai TSS lapangan. Hal tersebut dapat diketahui dari besar NMAE yang didapatkan. Seperti pada Algoritma Guzman \& Santaella (2009) yang memiliki nilai korelasi sedang yaitu 0,4, namun nilai NMAE yang dihasilkan sangat besar mencapai $8802 \%$, hal tersebut disebabkan oleh nilai TSS yang dihasilkan oleh Algortima Guzman \& Santaella (2009) berbeda jauh dengan hasil TSS lapangan.

\section{Analisa Perbandingan Nilai TSS Citra Landsat-8 pada 24 Agustus 2017 dengan Data In Situ}

Setelah uji korelasi dilakukan, didapatkan algoritma yang memiliki nilai NMAE terendah yaitu Algoritma Budhiman (2004) dengan nilai $N M A E$ sebesar $19,53 \%$. Nilai tersebut menunjukkan bahwa hasil TSS Algoritma Budhiman (2004) merupakan yang paling sesuai dengan hasil TSS lapangan dibandingkan dengan algoritma TSS lainnya. Untuk perhitungan TSS menggunakan algoritma lainnya memiliki perbedaan yang cukup menonjol antara citra dan data lapangan hal ini dapat disebabkan karena :

1. Perbedaan waktu perekaman citra dan waktu pengambilan data insitu. Waktu perekaman citra adalah Tanggal 24 Agustus 2017 pada pukul 02:35:51.038584, sedangkan waktu pengambilan data in situ dimulai pukul 9.35-14.30 WIB. Terdapat selang waktu yang signifikan antara waktu perekaman citra dan waktu pengambilan data in situ. Hal ini dapat mengakibatkan perubahan / dinamika kondisi perairan yang mengakibatkan perubahan sebaran dan nilai TSS.

2. Pengaruh radiometrik

Perbedaan nilai TSS citra dan In Situ dapat disebabkan karena pengaruh radiometrik atau gangguan perambatan gelombang di udara.

3. Perbedaan Karakteristik Perairan Studi Algoritma TSS dan Perairan Sidoarjo. Perbedaan yang menonjol dari hasil pengolahan citra dan data in situ dapat disebabkan karena karakteristik perairan Algoritma TSS yang digunakan dengan Perairan Sidoarjo berbeda. Seperti pada Algoritma [4]v yang memiliki nilai sangat jauh dimungkinkan karena studi kasus algoritma tersebut bertempat di Mayagüez Bay, Puerto Rico yang terletak sangat jauh, sedangkan pada Algoritma [3] memiliki perbedaan yang tidak terlalu menonjol dari nilai TSS lapangan, karena studi kasus pembuatan algoritma masih berada di dalam wilayah perairan Indonesia.berada di dalam wilayah perairan Indonesia.

D. Analisa Nilai Hasil TSS Pengolahan Citra Satelit Landsat 7 dan 8 Multitemporal

Setelah mengetahui algoritma yang memiliki nilai absolut error atau NMAE terendah adalah Algoritma Budhiman (2004), maka dilakukan perhitungan nilai TSS pada citra satelit landsat tahun 2000, 2013, 2014, 2015, dan 2016, untuk mengetahui kondisi konsentrasi TSS di Muara Sung ai Porong pada waktu itu. Adapun hasil perhitungan TSS pada tahuntahun tersebut adalah sebagaiberikut :
Tabel 3.3

Hasil Nilai TSS Tahun 2000, 2013, 2014, 2015, 2016, 2017, di Perairan Muara Sungai Porong

\begin{tabular}{lcccccc}
\hline \hline No & TSS & TSS & TSS & TSS & TSS & TSS \\
Titik & $\begin{array}{c}\text { Citra } \\
\text { Tahun } \\
\text { Citra } \\
\text { Tahun } \\
(\mathrm{mg} / \mathrm{L})\end{array}$ & $\begin{array}{c}\text { Citra } \\
\text { Tahun } \\
(\mathrm{mg} / \mathrm{L})\end{array}$ & $\begin{array}{c}\text { Citra } \\
\text { Tahun } \\
(\mathrm{mg} / \mathrm{L})\end{array}$ & $\begin{array}{c}\text { Citra } \\
\text { Tahun } \\
(\mathrm{mg} / \mathrm{L})\end{array}$ & $\begin{array}{c}\text { Citra } \\
\text { Tahun } \\
(\mathrm{mg} / \mathrm{L})\end{array}$ & $\begin{array}{c}2016 \\
(\mathrm{mg} / \mathrm{L})\end{array}$ \\
\hline 1 & 16,94 & 19,72 & 30,79 & 18,57 & 18,65 & 38,14 \\
\hline 2 & 15,46 & 17,02 & 22,59 & 14,11 & 14,46 & 32,77 \\
\hline 3 & 14,3 & 16,21 & 16,83 & 13,5 & 13,71 & 13,66 \\
\hline 4 & 14,69 & 13,29 & 16,64 & 13,77 & 14,37 & 14,79 \\
\hline 5 & 14,96 & 13,71 & 17,96 & 13,32 & 13,83 & 14,4 \\
\hline 6 & 16,79 & 13,62 & 19,5 & 12,91 & 13,93 & 12,68 \\
\hline 7 & 15,29 & 13,96 & 13,32 & 12,6 & 18,28 & 12,18 \\
\hline 8 & 15,57 & 14,82 & 12,18 & 14,56 & 25,25 & 11,86 \\
\hline 9 & 17,13 & 21,17 & 11,52 & 15,33 & 24,1 & 11,57 \\
\hline 10 & 17,14 & 33,36 & 10,8 & 14,86 & 23,25 & 11,5 \\
\hline 11 & 15,64 & 22,39 & 11,14 & 12,82 & 26,94 & 14,21 \\
\hline 12 & 17,17 & 24,42 & 11,55 & 13,03 & 30,52 & 14,5 \\
\hline 13 & 17,21 & 32,55 & 11,73 & 13,35 & 27,67 & 26,88 \\
\hline 14 & 18,9 & 31,91 & 13,38 & 13,71 & 25,94 & 24,48 \\
\hline 15 & 17,21 & 35,83 & 35,2 & 13,83 & 25,19 & 24,97 \\
\hline 16 & 22,84 & 35,27 & 35,12 & 13,47 & 29,45 & 20,52 \\
\hline 17 & 18,86 & 33,36 & 29,12 & 14,27 & 26,17 & 24,8 \\
\hline 18 & 18,82 & 36,39 & 33,21 & 15,19 & 22,29 & 27,24 \\
\hline 19 & 16,94 & 42,44 & 42,82 & 14,46 & 27,36 & 29,32 \\
\hline 20 & 18,48 & 42,25 & 38,05 & 18,48 & 25,19 & 29,38 \\
\hline \hline & & & & & & \\
\hline
\end{tabular}

Berdasarkan nilai TSS pada tabel di atas dapat dilihat bahwa nilai TSS tidak selalu naik, namun juga ada yang mengalami penurunan pada beberapa titik sampel pengamatan. Penurunan dan peningkatan nilai TSS berdas arkan titik pengamatan tersebut dapat dilihat lebih jelas pada grafik berikut :

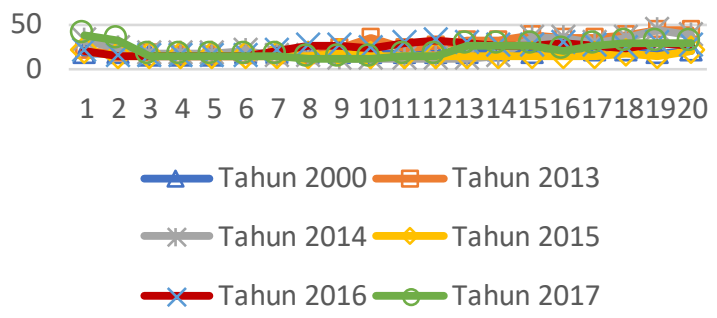

Gambar 3.1 Grafik Perubahan Konsentrasi TSSMultitemporal

Pada grafik 3.1 dapat dilihat bahwa nilai TSS yang paling tinggi adalah pada tahun 2014 yaitu mencapai 42,82 mg/L pada titik pengamatan nomor 19, sedangkan nilai TSS terendah terjadi pada tahun 2015 yaitu hanya berkisar antara 12,6 mg/L hingga 18,57 mg/L. Perubahan nilai TSS dari tahun ke tahun berdasarkan titik sampel pengamatan dapat dilihat pada peta sebaran konsentrasi TSS seperti berikut :

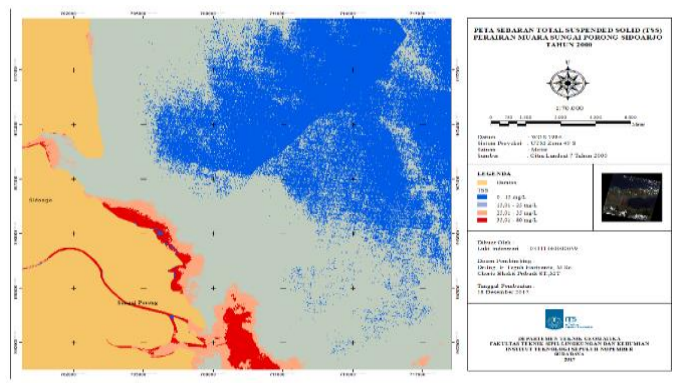

Gambar 3.2 PetaSebaran T SSPerairan Muara Sungai Porong Tahun 2000 


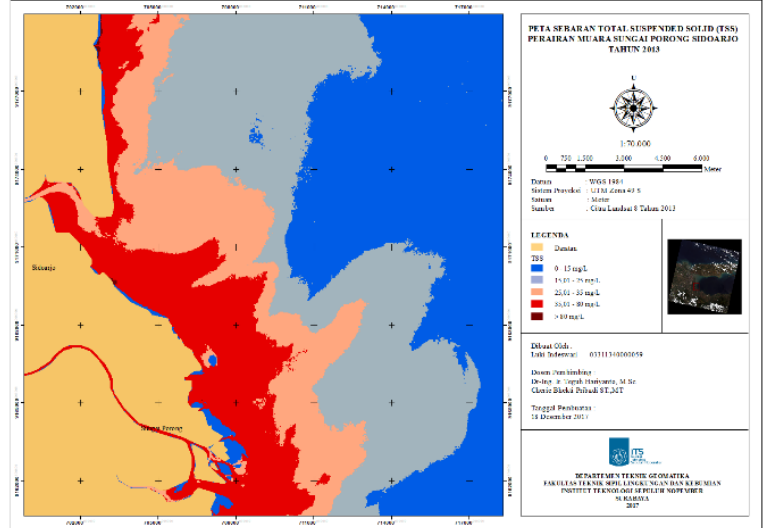

Gambar 3.3 Peta Sebaran T SS Perairan Muara Sungai Porong Tahun 2013
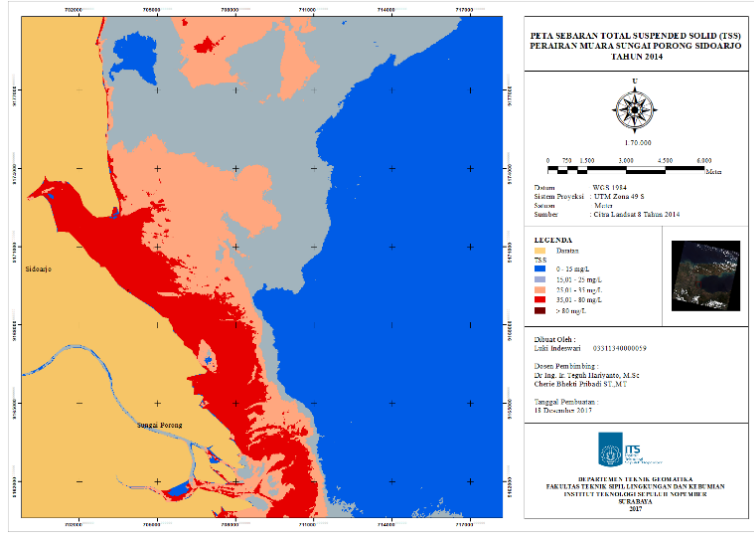

Gambar 3.4 Peta Sebaran T SS Perairan Muara Sungai Porong Tahun 2014
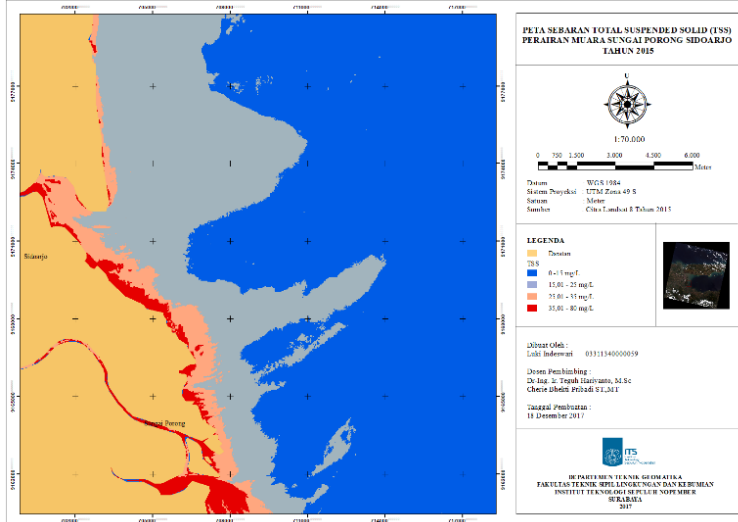

Gambar 3.5 Peta Sebaran T SSPerairan Muara Sungai Porong Tahun 2015
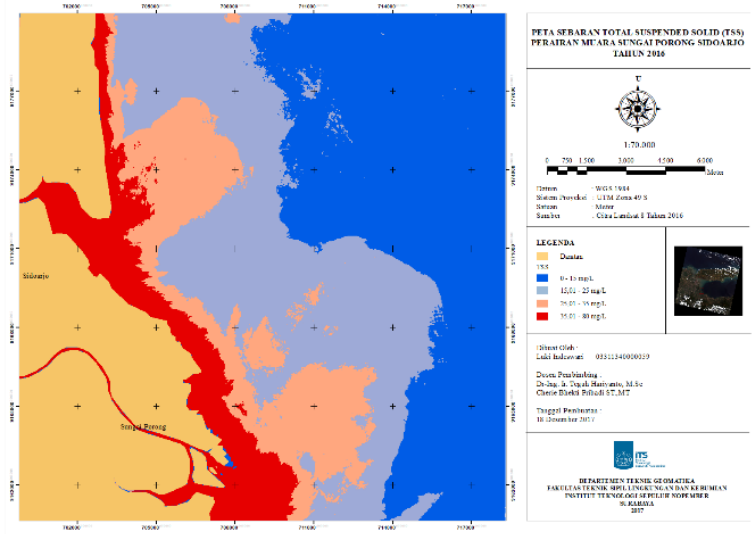

Gambar 3.6 Peta Sebaran T SSPerairan Muara Sungai Porong Tahun 2016

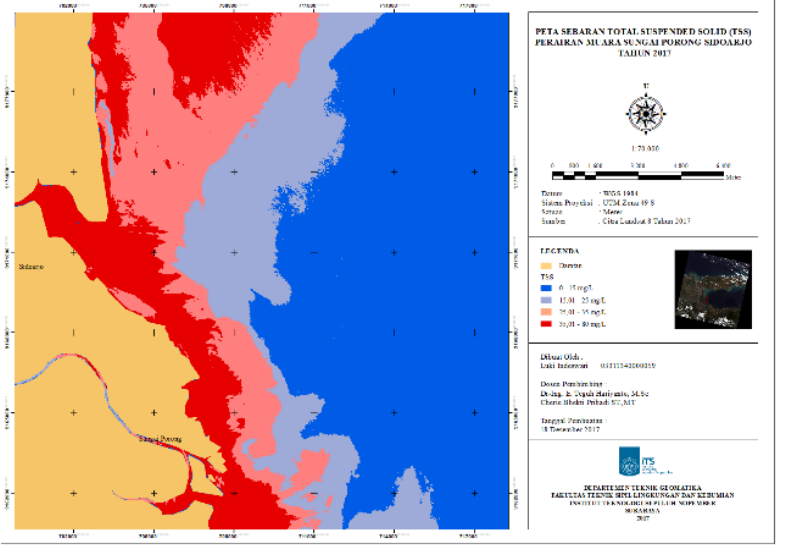

Gambar 3.7 Peta Sebaran T SS Perairan Muara Sungai Porong Tahun 2017

Dari peta sebaran konsentrasi TSS di atas, dapat dilihat bahwa konsentrasi TSS tiap tahunnya berubah-ubah. Daerah yang terkena dampak paling besar adalah di sekitar muara Kali Porong atau di dekat daratan, karena merupakan tempat bertemunya aliran sungai dan laut (gelombang dan arus) sehingga ada banyak material TSS yang terkonsentrasi di daerah tersebut Fluktuasi yang terjadi pada nilai TSS tiap tahunnya dapat disebabkan oleh :

- Pasang surut air laut, arus, dan angin.

Laju aliran air laut merupakan faktor utama dalam perubahan konsentrasiTSS. Air yang mengalir cepat membawa partikel dan sedimen yang lebih besar. Bila terjadi hujan lebat, pasir, lumpur, tanah liat, dan partikel organik lain dapat terbawa dari daratan ke laut.

- Pembusukan tanaman dan hewan laut

Adanya tanaman dan hewan di dalam laut yang mati dan membusuk akan melepaskan partikel organik tersuspensi yang dapat berkontribusi pada peningkatan ataupun penurunan nilai konsentrasi TSS

E. Evaluasi Nilai Hasil TSS Terhadap Keputusan Menteri Negara Lingkungan Hidup Nomor 51 Tahun 2004

Dalam Keputusan Menteri Negara Lingkungan Hidup No. 51 Tahun 2004 mengatur tentang parameterparameter apa saja yang harus dan tidak boleh dimiliki oleh air laut serta kadar maksimum yang diperbolehkan. Kawasan perairan laut di luar Perairan Pelabuhan dan Wisata Bahari mengacu pada Baku Mutu Air Laut untuk Biota Laut ${ }^{[4]}$.

Berdasarkan hasil pengolahan data citra satelit Landsat 7 dan 8 pada tahun 2000, 2013 hingga 2017, serta data in situ didapatkan hasil konsentrasi TSS di Perairan Muara Sungai Porong yang terendah pada tahun 2015 yaitu $10,22 \mathrm{mg} / \mathrm{L}$ hingga $60,08 \mathrm{mg} / \mathrm{L}$, dan tertinggi pada tahun 2013 dengan nilai TSS berkisar antara 11,52 mg/L hingga 92,16 mg/L, dan tahun 2014 yaitu berkisar antara $10,28 \mathrm{mg} / \mathrm{L}$ hingga $81,17 \mathrm{mg} / \mathrm{L}$. Maka dari itu, pada tahun 2013, dan 2014 memiliki nilai konsentrasi TSS melewati batas standar baku mutu air laut menurut Keputusan Menteri Negara No. 51 Tahun 2004 yaitu 80 mg/L. 


\section{KESIMPULAN}

Berdasarkan hasil penelitian mengenai Pemetaan Persebaran TSS (Total Suspended Solid) di Perairan Muara Sungai Porong Sidoarjo dengan Memanfaatkan Citra Satelit Landsat 7 dan 8 Multitemporal dan Data In Situ, maka didapatkan beberapa kesimpulan akhir yaitu:

1. Berdasarkan hasil pengolahan data in situ dan data Citra Satelit Landsat-8 L1T Pada Tahun 2017 dengan menggunakan 4 Algoritma yang telah ditentukan, yaitu Algoritma Syarif Budhiman (2004), Algoritma Parwati (2006), Algoritma Guzman \& Santaella (2009), serta Algoritma Nurahida Laili (2015) didapatkan hasil uji validasi NMAE dengan absolut error terendah yaitu Algoritma Budhiman (2004) sebesar 19,53\% yang menunjukkan bahwa hasil TSS algoritma tersebut masih sesuaidengan TSS lapangan yang didapatkan.

2. Nilai TSS pada tahun 2000, 2013 hingga 2017 yang didapat dari pengolahan Citra Satelit Landsat 7 dan 8 dengan menggunakan Algoritma Budhiman (2004) secara keseluruhan mendapatkan hasil terendah antara $10,22 \mathrm{mg} / \mathrm{L}$ hingga $60,08 \mathrm{mg} / \mathrm{L}$ pada tahun 2015 , dan tertinggi pada tahun 2013 dengan nilai TSS dengan nilai TSS berkisar antara 11,52 mg/L hingga 92,16 mg/L.

3. Berdasarkan hasil pengolahan data citra satelit Landsat 7 tahun 2000 dan Landsat 8 tahun 2013 hingga 2017 menggunakan Algoritma Budhiman (2004) didapatkan hasil nilai konsentrasi TSS tertinggi pada tahun 2013, dan 2014 yaitu 92,16 mg/L, dan 81,17 mg/L secara berurutan. Maka dari itu, pada tahun tersebut perairan di Muara Sungai Porong dapat dikatakan tercemar karena melebihi baku mutu air laut untuk biota laut yang telah ditentukan pada KepMenLH Nomor 51 Tahun 2004 tentang Baku Mutu Air Laut untuk biota laut yaitu sebesar $80 \mathrm{mg} / \mathrm{L}$.

\section{DAFTAR PUSTAKA}

[1] M. Saeni, "Biologi Air Limbah,” IPB, 2003.

[2] S. Budhiman, "Mapping TSM Concentrations From Multi Sensor Satellite Images in Turbid Tropical Coastal Waters of Mahakam Delta Indonesia," ITC Enschede, 2004.

[3] E. Parwati, “Analisis Dinamika Fluktuasi Tss (Total Suspended Solid) Sepanjang Das-Muara-Laut Di Perairan Berau Kalimantan Timur," 2014.

[4] V. Guzman, "Using MODIS $250 \mathrm{~m}$ Imagery to Estimate Total Suspended Sediment in a Tropical Open Bay," Int. J. Syst. Appl., vol. 3, no. 1, 2009.

[5] L. Nurahida Laili, "Development Of Water Quality Parameter Retrieval Algorithms For Estimating T otal Suspended Solids And Chlorophyll-a Concentration Using Landsat -8 Imagery at Poteran Island Water," 2015.

[6] L. M. Jaelani, R. Limehuwey, N. Kurniadin, and A. Pamungkas, "Estimation of TSS and Chl - a Concentration from Landsat 8 OLI : The Effect of Atmosphere and Retrieval Algorithm," 2016. 